UDK: 801.3

Izvorni znanstveni članak

Primljen 27. II. 2020.

Martina JUKIĆ

Burghausen

martina.matic.m@gmail.com

\title{
LEKSIČKO-SEMANTIČKI ODNOSI SUPROTNOSTI UVJETOVANI KONTEKSTOM
}

\section{Sažetak}

U radu se analiziraju odnosi semantičke suprotnosti među riječima u feljtonima (En Passant) i esejima (Sadašnjost za vječnost - izbor iz djela) Veselka Tenžere, posebice oni uvjetovani kontekstom. Kako takvi odnosi nisu uočljivi izvan navedenoga konteksta, tu pojavu nazivamo antonimičnost.

Na početku rada navedeni su primjeri prave suprotnosti, antonimije, no zbog konteksta u koji su smješteni i oni doprinose većoj ekspresivnosti jezika i stilskoj dotjeranosti izraza. Ekspresivnost i stiliziranost izraza osobito je vidljiva u drugome dijelu rada u kojem su izdvojeni izrazi i sintagme međusobno suprotni isključivo zbog konteksta - antonimičnosti. Primjeri takve suprotnosti, postignute uporabom stilskih figura ili stavljanjem različitih riječi u neobične sveze, utječu na stilsku izražajnost, osobito kada se radi o višečlanim antonimičnim izrazima čija se površinska struktura u potpunosti gubi iz vida zbog konteksta, a povećava se ekspresivnost teksta.

Ključne riječi: leksičko-semantički odnos; antonimija; antonimičnost; kontekst; Veselko Tenžera; esej; feljton; ekspresivnost; stiliziranost 


\section{Uvod}

Kada se radi o leksičko-semantičkim odnosima među riječima, jednomu izrazu uvijek pridružujemo jedan sadržaj (jednomu formativu jedan semem ${ }^{1}$ ) pa taj izraz ima uvijek isto značenje bez obzira na kontekst ${ }^{2}$. Kada postoji takav odnos među riječima, onda govorimo o monosemiji ili jednoznačnosti, ali on je rijedak u bilo kojem jeziku, osim ako se radi o pojmovima, emocionalno obojenim riječima i slično ${ }^{3}$. Mnogo su češći izrazi (riječi) koje imaju više značenja, pa u tome slučaju govorimo o semantemima ili kompleksima značenja koji su u međusobnoj svezi, dakle višeznačnice ili polisemične riječi. ${ }^{4}$

Za rad su važnije višeznačne ili polisemične riječi, a sama se pojava, polisemija, smatra jednom od ključnih pojava u semantici ${ }^{5}$. Polisemija je poželjna u svakome prirodnom jeziku jer se njome ponajviše poštuje načelo ekonomičnosti čime se sprječava neograničeno širenje rječnika. Premda polisemija obuhvaća više značenja jedne riječi, ta se riječ smatra jednom jedinicom jezika jer upravo njezina unutrašnja heterogenost, višestrukost i različitost značenja, uvjetovana kontekstom, ne narušavaju identitet riječi, već upravo zajednički oblik i semantički elementi značenja „osiguravaju jedinstvo polisemičke riječi kao lingvističkog znaka“6. Nešto drukčije određenje polisemije ponudio je Zdenko Lešić koji taj odnos stavlja u opreku sa sinonimijom: „U svim jezicima se susrećemo

1 Usp. Jasna Melvinger, Leksikologija, Pedagoški fakultet, Osijek, 1989., str. 27.

2 Više o odnosu značenja i konteksta vidi u: LjILjANA ŠArIĆ, „Kognitivna lingvistika i sinonimija: teorija i leksikografska praksa“, Croatica et Slavica Iadertina, Zadar, god. VII.(II.) (2011.) br. 7., str. 305. - 325.; Elisabeth Black, Pragmatic Stylistics, Alan Davies - Keith Mitchell (ur.), Edinburgh University Press, Edinburgh, 2006.

3 Marko Samardžija navodi da su takve riječi, jednoznačnice, brojne u svakoj vrsti punoznačnih riječi i nisu dio samo pasivnoga leksika, nego nastaju i danas jer jednoznačnost ili monosemija je pojava starija od polisemije koja nastaje značenjskim proširenjem jednoznačnice. (usp. Marko SAMARDžIJA, Leksikologija hrvatskoga jezika i povijest hrvatskoga jezika u XX. stoljeću, Školska knjiga, Zagreb, 1995., str. 11.)

4 Usp. J. Melvinger, $n$. dj., str. 27.

5 Usp. isto, str. 27. Autorica polisemiju određuje ovako: „Vodeći računa o mogućnosti raščlanjivanja semema na komponente polisemiju možemo definirati i na sljedeći način: to je veza jednog formativa i dva ili više kompleksa komponenata što su uvijek relativno tijesno sematički povezani, a moraju se razlikovati po najmanje jednoj komponenti.“ (Isto, str. 29.)

6 J. Melvinger, $n$. $d j$., str. 27. 
sa pojavom da nekoliko 'oznaka' može biti povezano sa jednim smislom i, obrnuto, nekoliko smislova sa istom 'oznakom'. U oba slučaja nastaju posebne semantičke pojave, nazvane sinonimija, odnosno polisemija."7 Sam pristup značenju različit je u strukturalnoj i prototipnoj semantici, s kojom se djelomično preklapaju stavovi dinamičke semantike.

Strukturalističko poimanje značenja dugo je prevladavalo u lingvistici ${ }^{8}$, a polazi od toga da je značenje jezičnoga znaka određeno njegovim sintagmatskim i paradigmatskim odnosima s drugim znakovima i prema tomu jezični je znak uvijek u opoziciji s drugim znakovima, ili o njima ovisi ili se od njih razlikuje nekim od razlikovnih obilježja. ${ }^{9}$ Takav su pristup značenju, počevši od De Saussurea, dalje razvijali Trier, Weisgerber, Cruse i dr., a glavna je zamjerka strukturalističkim teorijama općenito to što zanemaruju kontekst u kojem se jezične jedinice ostvaruju.

Prototipno se ili stereotipno poimanje značenja „određuje kao fleksibilna, promjenjiva i rastezljiva veličina" ${ }^{10}$ te se u potpunosti razlikuje od strukturalističkoga pristupa u kojem je značenje statično. Ovo su poimanje značenja u najvećoj mjeri zastupali Putnam i Rosch, poslije Schwarze, dok je nedostatke ove teorije najsustavnije prikazao Tsohatzidis ${ }^{11}$.

Prema teoriji dinamičke semantike značenja izraza jesu „stereotipi koji se mogu realizirati individualno. Stereotipi su hipoteze o strukturi i o odnosima paradigmatskih postupaka općih pojmova/vrsta. Snaga (jakost, moć) stereotipa određena ekstenzionalno različita je od konteksta do konteksta. Stereotipi preuzimaju ulogu semantičkih obilježja, jer mogu asocirati na više drugih stereotipa. ${ }^{{ }_{12}} \mathrm{Na}$ oblikovanje ove teorije značenja najviše je utjecala Putnam, ali za razliku od prethodnih dviju, dinamička teorija značenje određuje kao jedinicu jezika u potpunosti ovisnu o kontekstu, a najgorljiviji zastupnik ove teorije je Kindt.

\footnotetext{
ZDENKo LEŠIĆ, Jezik i književno djelo, Zavod za izdavanje udžbenika, Sarajevo, 1971., str. 90.

8 O važnosti i prinosima strukturalističkoga poimanja značenja i sinonimnih odnosa pisala je Ljiljana Stančić (vidi: LJILJANA STANČić, Sustavnost leksika i sinonimne relacije u klasičnom strukturalizmu, Institut za jezik, Sarajevo, 1991., str. 229. - 246.)

9 Usp. Bernardina Petrović, Sinonimija i sinonimičnost u hrvatskome jeziku, Hrvatska sveučilišna naklada, Zagreb, 2005., str. 97.

10 B. Petrović, $n$. $d j$., str. 101.

${ }_{11}$ Usp. isto, str. 104.

${ }_{12}$ Isto, str. 105.
} 
Za proučavanje i utvrđivanje značenjskih odnosa među riječima osobito je važna značenjska raščlamba koja značenje razlaže na značenjske sastojnice ili semantičke komponente. ${ }^{13}$ Analiza se provodi s obzirom na odsutnost odnosno prisutnost neke od značenjskih sastojnica, pa će tako, primjerice, riječi muškarac ('odrasla osoba muškoga spola') i dječak ('muško dijete do puberteta') dijeliti sastojnice (+ljudsko) i (+muško), a razlikovat će se u sastojnici (+odraslo) koja je prisutna u značenju riječi muškarac, a odsutna (-odraslo) u riječi dječak. Spomenuti značenjski odnosi među riječima mogu biti inherentni i uvjetovani kontekstom, a ostvaruju se kao antonimija, homonimija, sinonimija i paronimija ${ }^{14}$.

U radu će se analizirati odnosi semantičke suprotnosti među riječima u feljtonima (En Passant) i esejima (Sadašnjost za vječnost - izbor $i z$ djela) Veselka Tenžere, posebice takvi značenjski odnosi suprotnosti uvjetovani kontekstom.

\section{Antonimija i kontekst}

$\mathrm{S}$ obzirom na to da je $\mathrm{u}$ radu naglasak na odnosima suprotnosti koji se trebaju promatrati i kao kontekstom uvjetovani ${ }^{15}$, ukratko će se odredit pojam konteksta i njegova uloga u stvaranju uvjeta za postojanje tih odnosa. Društveni, socijalni, duhovni i materijalni uvjeti utječu na formiranje ljudi i njihovih misli, a samim time i na leksik koji koriste i prenose na sljedeće generacije. U tome smislu možemo promatrati i pojedine jezične jedinice/znakove koji se ostvaruju na odnosima izraza - sadržaja - predmeta i ukazati na to kako leksik nekoga jezika ne čine „neovisne i samostalne leksičke jedinice koje se mogu promatrati samo u zatvorenim relacijama našeg semantičkog dijagrama ${ }^{{ }_{116}}$, nego ga

\footnotetext{
Usp. M. SamardžIJA, $n$. $d j$., str. 12.

Usp. Marina Katnić-BaKaršıć, Stilistika, Ljiljan, Sarajevo, 2001., str. 227.

Upravo se kontekst koristi kao kriterij u podjeli određenih leksema, primjerice u podjeli sinonima Marko Samardžija razlikuje općejezične i kontekstualne sinonime (usp. M. SAMARDžıJA, $n$. dj., str. 20). Kada analizira situacijski motivirane varijante, Krunoslav će Pranjić reći da su kontekstualna motivacija i kontekstualna realizacija veliki regulatori vrijednosti leksičkih varijanata. (usp. Krunoslav Pranjıć, Jezik i književno djelo. Ogledi za lingvostilističku analizu književnih tekstova, Školska knjiga, Zagreb, 1968., str. 87.)

16 Z. LEŠıć, $n$. dj., str. 98.
} 
dobivaju u međusobnim odnosima - u činu se govora, primjerice, leksemi stavljaju u kontekst koji određuje značenje. ${ }^{17}$ Međutim, na ovaj način ne možemo u potpunosti odrediti što taj leksem doista znači i je li dobro uporabljen. Stoga su kao rješenje neki leksikografi predlagali promatranje leksema u akciji, tj. u različitim kontekstima, u nastojanju

da otkriju zajednički faktor koji omogućava da se riječi u njima pojavljuju, dakle onaj De Saussureov princip identiteta, te najzad da na osnovi njega definiraju jedno ili više značenja dane riječi. Budući da je jezik ( $l a$ langue) apstrakcija izvedena iz stvarne jezične upotrebe u živoj riječi ( $l a$ parole), onda je i leksičko značenje jednog izraza apstrakcija identiteta njegove upotrebe $\mathrm{u}$ različitim kontekstima. ${ }^{18}$

Upravo zbog toga što je jezik apstrakcija koja konkretnom postaje u stvarnome govoru, smatra se da puno značenje neke riječi dobivamo upravo zbog konteksta u kojem se našla, situaciji u kojoj je izgovorena i kulturi kojoj pripada. ${ }^{19}$

$\mathrm{Na}$ odnose među jezičnim jedinicima utječu i osobne, književne, ideološke, kulturne, društvene i druge okolnosti u kojima je to djelo nastalo i „predstavljaju najširi kontekstualni krug: djelo se uvijek pojavljuje u jednom takvom krugu, i tek u njemu se konačno određuju značenja jezičnih struktura koje djelo izgrađuju. ${ }^{20}$ Sve navedeno upućuje na to da se $\mathrm{u}$ analizi koja slijedi ne ćemo $\mathrm{u}$ potpunosti moći osloniti na jezične priručnike jer kontekst uvjetuje značenje koje ne nalazimo za sve primjere u rječničkome članku, a osim toga radi se o autorskome tekstu pa se mogu očekivati miješanja svake vrste. ${ }^{21}$

\footnotetext{
Usp. isto, str. 103.

Z. LEŠIĆ, $n$. dj., str. 109.

Stephen Ullmann, Language and Stile, Basil Blackwell, Oxford, 1964., str. 25. citirano prema Z. LEŠIĆ, $n$. dj., str. 109. Ullmann inače za bliskoznačnice koristi izraz homoionimi ( Stephen Ullmann, Principles of Semantics, Jackson - Basil Blackwell, Glasgow - Oxford, 1957., str. 109., citirano prema: BranKa TAFrA, Od riječi do rječnika, Školska knjiga, Zagreb, 2005.)

20 Z. LEŠIĆ, $n$. dj., str. 112.

${ }^{21} \quad$ Usp. B. TAFra, $n . d j .$, str. 217.
} 


\section{Leksičko-semantički odnosi suprotnosti}

U lingvistici se antonimija (grč. antí - protu, ónoma - ime) proučavala manje od sinonimije, a veća pozornost posvećuje joj se razvojem strukturalne lingvistike kada se antonimija ${ }^{22}$ dovodi u vezu s ekspresivnim čimbenicima u stilistici ${ }^{23}$. U svome se djelu Antonimija $u$ hrvatskome jeziku Ljiljana Šarić posebice osvrće na rad Johna Lyonsa koji se bavi proširenjem uskoga poimanja antonimije te navodi značenjske opreke triju različitih vrsta: komplementarnost, antonimija i konverzija ${ }^{24}$, pri čemu antonimna suprotnost svoj poseban jezični izraz nalazi u svim aspektima semiotike, semantici, sintaktici i pragmatici. ${ }^{25}$ Slično je i kod Christine Römer i Brigitte Matzke koje razlikuju četiri odnosa suprotnosti: kontradiktornost, antonimija, konverzija i inkompatibilnost, a pod antonimijom podrazumijevaju samo krajnje stupnjeve na skali suprotnosti ${ }^{26}$. Tako antonimiju određuje i Jasna Melvinger, navodeći još i heteronimiju i komplementarnost kao vrste odnosa suprotnosti među riječima. Tako će ona antoniman odnos odrediti kao, kao i komplementarnost, suprotan odnos u koji stupaju samo parovi riječi, dakle binarni odnos, a od komplementarnosti se razlikuje po vrsti suprotnosti. Antonimni izrazi specificiraju referencijalno područje jer ga ne obuhvaćaju u

${ }^{22}$ Antonimija se definira kao odnos suprotnosti, semantičke različitosti među riječima, leksičko-semantička pojava značenjske opreke (vidi: STJEPAn BABIĆ, Jezik, Panorama, Zagreb, 1967.; J. Melvinger, $n$. dj.; M. SAmardžIja, $n$. dj.).

${ }_{23}$ Tako će se na antonimnome odnosu, dakle suprotnome odnosu, temeljiti i neke stilske figure kao što su antiteza, oksimoron, a dio je i svakodnevne komunikacije o čemu svjedoče brojne poslovice i frazemi.

24 Usp. LJ. ŠArIĆ, Antonimija u hrvatskome jeziku..., str. 43.

${ }_{25}$ Usp. LJ. Šarić, Antonimija u hrvatskome jeziku..., str. 44. - 45. Vidi i: LjILjana ŠArić, „Antonimija: neke značenjske i tvorbene odrednice“, Rasprave ZHJ, god. XVIII. (1992.) br. 1., str. 177. -191.

26 Usp. „Die Andersseinrelation tritt in vier Ausprägungen auf: Kontradiktion: Eine Kontradiktion bilden zwei Kontrastwörter, sie stehen in einem Polaren Gegensatz (tot - lebendig); Antonymie: Eine antonymische Relation liegt vor, wenn zwischen zwei Kontrastwörtern Lexeme zur Bezeichnung der Zwischenstufen existieren (heiß - warm - lauwarm - kalt eiskalt); Konversion: Konverse sind Lexeme, deren Bedeutung 'spiegelbildlich' aufeinander bezogen ist (kaufen - verkaufen); Inkompatibilität: Als inkompatibel bezeichnet man die Relation in aufeinander bezogenen, geschlossenen Wortreihen (Norden - Osten - Süden - Westen)“. (Christine Römer - Brigitte Matzke, exikologie des Deutschen. Eine Einführung, Gunter Nar Verlag, Tübingen, 2005., str. 53. - 54.) 
cijelosti, nego samo određene dijelove. Prema Melvinger, antoniman je odnos stupnjevit ${ }^{27}$, a antonimni se izrazi odnose samo na krajnje stupnjeve, na polove, što znači da u takvu odnosu postoje i treći članovi, međustupnjevi, koje ona definira kao „ni semem 1 ni semem $2^{“{ }_{28} 8}$. Vrlo se često takvi odnosi suprotnosti uspostavljaju na temelju iskustva.

I za antonime, kao i sinonime, vrijedi da u semantičke odnose stupaju polisemične jezične jedinice, pa će bitan čimbenik biti kontekst koji određuje koje će značenje biti aktualizirano, osobito kada se analizi antonimnih odnosa pristupa sa sintagmatskoga i pragmatičkoga aspekta (uz navedene Šarić spominje i paradigmatski aspekt ${ }^{29}$ ). Prema tomu i najopćenitija je podjela antonima na kolektivne i kontekstualne. Osnovni kriterij te podjele vezan je za prepoznavanje antonima među govornicima određenoga jezika, odnosno hrvatskoga jezika. Ako govornici hrvatskoga jezika mogu tvoriti antonimne parove izvan konteksta, ako su im općepoznati, onda su to općejezični (kolektivni) antonimi. Ako im je za prepoznavanje antonimnoga odnosa potreban kontekst, onda su to kontekstualni antonimi..$^{30}$

${ }_{27}$ Za istu vrstu antonimnoga odnosa rabi se i pojam gradacijski antonimi (usp. MARIjA TURK, „Neka odstupanja u antonimskoj simetriji u hrvatskom jeziku“, Fluminensia, Rijeka, god. XVI. (2004.) br. 1. - 2., str. 92.)

28 Usp. J. Melvinger, $n$. dj., str. 51. Komplementarnost (lat. complere - ispuniti, upotpuniti) određuje kao isključivo binaran odnos suprotnosti, dakle komplementarni leksemi uvijek tvore parove riječi i upravo je to obilježje koje komplementarnost razlikuje od heteronimnosti u kojoj broj članova nije unaprijed ograničen. Ako se radi o ovakvoj vrsti suprotnosti, onda je ona uvijek kontradiktorna, npr. referencijalno područje spol može imati izraz muškarac ili žena, dakle jedan izraz ima pozitivan predznak (+ muško), a drugi negativan (- muško). Samim time, osim što je binaran, komplementarni odnos među leksemima je i isključni odnos jer izraz Ovo je muškarac implicira negaciju Ovo nije žena. Najčešće se javlja kod pridjeva (živ - mrtav, istinit - lažan, čist - prljav) te priloga i imenica. Komplementaran je odnos i među pridjevima od kojih je jedan tvoren nekim od negacijskih prefiksa: oženjen - neoženjen, simetričan - asimetričan, uman - bezuman i dr. komplementarne su i imenice čiji izrazi sadrže komplementarne specifikacije, npr. čovjek (+ljudsko) - životinja (-ljudsko), dječak (+muško) - djevojčica (-muško) (usp. isto, str. 50. - 51.)

29 Usp. LJ. ŠArIĆ, Antonimija u hrvatskome jeziku..., str. 58.

3o Usp. M. Samardžija, $n$. dj., str. 24. Važno je napomenuti da Marko Samardžija navodi nešto drukčiji kriterij podjele antonima: po podrijetlu: raznokorijenski (istina - laž) i istokorijenski (sreća - nesreća); po naravi značenjske opreke: komplementarni (istina - laž), stupnjeviti (visok - nizak) i obratni (pradjed - praunuk); po usvojenosti: općejezični i kontekstualni. (Usp. isto, str. 22. - 23.) 
Uključivanjem standardnojezičnih antonima u kontekst nastaju situacijski antonimni parovi koji se teško mogu svrstati u određeni tip, bez konteksta, pa je i njihova antonimnost upitna. U ovome će se slučaju za suprotan odnos među leksičkim jedinicama uvjetovan kontekstom koristiti pojam antonimičnost, a pojam je tvoren analogno pojmu sinonimičnost ${ }^{31}$ koji rabi Bernardina Petrović za sinonime čiji je odnos sličnosti/istosti uvjetovan kontekstom. Kao i kod sinonima javlja se i pojam kvaziantonima koji je uveo Apresjan, odnosno "prividnih antonima" ${ }^{\text {"32. }}$ Kada se radi o klasifikaciji antonima, češće se opisuje strukturna nego semantička klasifikacija antonima. U hrvatskome se jeziku u strukturnoj klasifikaciji antonima razlikuju: raznokorijenski, istokorijenski antonimi te enantiosemija, koja nije produktivna u suvremenome jeziku, a definira se kao „suprotnost različitih značenja riječi “ ${ }^{33}$. Antonimne osobine najčešće nalazimo kod pridjeva (malen - velik, kratak - dugačak, mršav - debeo), priloga (sporo - brzo, rano - kasno) te imenica (blagost - strogost, gorostas - patuljak, ljubav - mržnja, ružnoća - ljepota). Antoniman je odnos moguće tvoriti i dodavanjem riječice ne jednomu od izraza, npr. ljubazan - neljubazan, prijatelj - neprijatelj, sreća - nesreća. Budući da suprotan odnos među pridjevima može biti i komplementaran i antoniman, osnovna je razlika između tih dviju vrsta suprotnosti $\mathrm{u}$ tome što se antonimni pridjevi uvijek mogu usporediti, a komplementarni nemaju uvijek komparaciju. ${ }^{34}$

Analizi antonima/antonimičnosti pristupit će se na sljedeći način: $u$ prvome će se dijelu analizirati pravi antonimi, a u drugome dijelu primjeri antonima uvjetovani kontekstom - antonimičnost. Manjkavost $\mathrm{u}$ analizi predstavlja nepostojanje rječnika antonima u hrvatskome jeziku pa će se koristiti popis antonima koji Ljiljana Šarić navodi na kraju knjige Antonimija u hrvatskome jeziku: semantički, tvorbeni i sintaktički opis i određeni priručnici hrvatskoga jezika ${ }^{35}$, za one koji se ne navode.

\footnotetext{
Vidi: B. Petrović, $n . d j$.

LJ. ŠArIć, Antonimija u hrvatskome jeziku..., str. 80.

Isto, str. 83 .

Usp. J. MeLvinger, $n$. $d j$., str. 50. -51.

Rječnik hrvatskoga jezika, JuRe Šonje (ur.), LZ „Miroslav Krleža“ - ŠK, Zagreb, 200o.; VLADimir Anić, Veliki rječnik hrvatskoga jezika, Novi Liber, Zagreb, 2006.; Vladimir Anić i
} 
Važno je napomenuti da je Šarić u navedenome popisu antonime klasificirala s obzirom na kvalitativnu, koordinacijsku, komplementarnu, vektornu i konverzivnu suprotnost ${ }^{36}$, pa će se primjeri pronađeni u tome popisu izdvojiti s obzirom na pridruženu vrstu suprotnosti.

a) Za označene antonime Šarić navodi da su komplementarne prirode, dakle članovi opreke obuhvaćaju vrsni pojam u cijelosti. Prvo su navedeni primjeri iz eseja:

Riječ i boja su paralele koje se ne susreću ni u dubini relativizirana kozmosa, a sličnost „priče“ u pjesmi i slici više duguju razlici materijala u kojima postoje nego podudarnosti „priča“. (133)

U popisu se antonima nalaze pridjevi različit - podudaran, na osnovi čega se može pretpostaviti da je takav odnos i između imenica, a osim podudaran navodi se i leksem sličan te leksemi isti, jednak s kojima su u bliskoznačnome odnosu.

Otišao je, dakle, pisac koji podjednako pripada nekoj lirskoj utopiji i stvarnosti, koji je podjednako ispisao tragiku postojanja i „sretna prostranstva" mašte. (155)

U popisu se donose primjeri za pridjeve, pa za stvaran kao antonimni

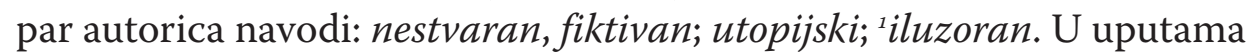
za uporabu popisa antonima navodi da znak (;) znači da su leksemi navedeni u nizu u bliskoznačnome odnosu, a u ovome slučaju eksponat ispred leksema iluzoran znači da je on s leksemom stvaran u kvalitativnome odnosu.

dr. (ur.) Hrvatski enciklopedijski rječnik, Novi Liber, Zagreb, 2003.; Šıme Anıć - NikolA Klaić - Želimir Domović, Rječnik stranih riječi, Sani-plus, Zagreb, 2002.; Enciklopedija. $h r,<w w w . e n c i k l o p e d i j a . h r .>$

36 Usp. LJ. ŠArIĆ, Antonimija u hrvatskome jeziku..., str. 97. - 114. Navedena klasifikacija je s obzirom na prisutnost/odsutnost nekih od sljedećih obilježja: ista/različita pojava (denotacija), usmjerenost/neusmjerenost i stupnjevitost/nestupnjevitost. Istu klasifikaciju koriste AnĐela Frančić - Milica Minaljević, „Antonimija u hrvatskoj ojkonimiji“, Rasprave IHJJ, Zagreb, god. XXIII. - XXIV. (1997. - 1998.) br. 1., str. 77. - 102. Vidi i: MiLICA MIHALJEVIĆ - LJILJANa ŠARIĆ, „Terminološka antonimija“, Rasprave ZHJ, Zagreb, god. XX. (1994.) br. 1., str. 213. - 243. 
Slijedi nekoliko primjera suprotnoga odnosa izdvojenih iz feljtona:

Umjesto bogomdanoga pojedinca, na scenu svijeta iz stoljetne prisilne tame izlazi masa, izlaze narodi... (13)

Antonimičnost izdvojenih izraza temelji se na odnosu jedno - mnoštvo.

Ne zaboravimo da smo stoljećima, na veoma malome prostoru, imali više crkava od bilo kojega kršćanski favoriziranoga naroda, i da je kultura smrti bila razvijena na račun nekulture života. (16)

U izdvojenim primjerima imamo dva različita odnosa suprotnosti, leksemi smrt i život u komplementarnu su odnosu, a leksemi kultura nekultura u kvalitativnome. Takvom dvostrukom suprotnosti dodatno se povećava stilska markiranost izraza.

Pokore bijahu užasne, a da i ne spominjemo lomače na kojima se cvrljilo erotizirano meso nerealiziranih i realiziranih potenata. (14)

Navedene lekseme nalazimo u rječniku u suprotnu odnosu, a uz nerealan kao antonimi navode se još fiktivan i irealan.

Stavljao je sebe sama kao sliku i neba i zemlje, kao prostor i granice života, bez klečanja i stida pred oltarom genitalija. (17)

...potrebno je zagledati se u najsivlje lice i prepoznati crtu napoelonskoga sna o posjedovanju svijeta milom ili silom. (30)

Izdvojeni primjeri su u obliku fraze navedeni i u rječniku.

b) Sljedeće antonime karakterizira koordinacijski odnos, što znači da se radi o odnosu kojim se označuje položaj u vremenu i prosto$\mathrm{ru}$, a s kvalitativnim antonimima dijele zajedničko svojstvo - ne označuju usmjerenost. Slijedi nekoliko primjera iz eseja:

I kao po nekome pravilu, sva velika imena lijeve književnosti prije revolucije gubila su se sa scene, milom ili silom, poslije revolucije. (167) 
Vlačić od mirnoga učenjaka postaje putnik od grada do grada, uz dvije ženidbe i osamnaestero djece. (...) Oko Malanchtona, humanista sklona kompromisima, roje se „filipisti“, a oko Vlačića, zakleta čistoći ideje i beskompromisnosti, skupljaju se "flacijaneri“. Desnica i ljevica, rekli bismo danas. (109)

Za antonimni par desnica - ljevica navodi se da su koordinacijski antonimi. U paru kompromis - beskompromisnost postoji razlika u značenju jer kompromis označava sadržaj, a beskompromisnost svojstvo. Ipak možemo reći da su navedeni leksemi u suprotnome odnosu i to, s obzirom na način tvorbe, radi se o komplementarnoj suprotnosti.

Navodimo nekoliko primjera iz feljtona uz napomenu da su u prethodnim primjerima komentirani neki odnosi među leksemima, pa u slučaju kada se ponavljaju, nećemo ponovno objašnjavati:

To je onaj tip što čuči na svima našim dnevnim i noćnim putovima... (53) ...svi su jurišali na njezino tijelo, a nitko na dušu. (55)

U izdvojenim primjerima koordinacijski odnos postoji između leksema svi - nitko, dok su leksemi tijelo - duša u komplementarnu odnosu.

S težištem prebačenim ulijevo, s desnom nogom preko lijeve ruke, na naslonu, a uska glava, s nosom svađalice, napokon umirena, kao misao. (7o)

Odnos između leksema desni - lijevi objašnjen je u nekom od prethodnih primjera pa ga ovdje nećemo ponavljati.

Kad smo već kod tih nesretnih bedara, da malo razmotrimo taj prvi i posljednji problem urbane filozofije. (79)

c) Navedeni antonimni odnosi jesu primjeri vektorne suprotnosti, dakle ovakvom se suprotnosti izražavaju različito usmjerene radnje, obilježja, odnosi i sl. navodimo prvo primjere iz eseja:

Začinje se, sve u svemu, novi humanist većih dimenzija, um predestiniran za duhovne pustolovine u skladu sa svojim vremenom, pero koje 
pohvale i pokude, piše na određene adrese tako obične u tom drugom djetinjstvu Europe. (111)

„Prateći vod“ uglavnom je šutio i hvalio ili kudio i jedne i druge. (172)

Uz kuditi kao antonim javljaju se još i rugati se, izrugivati se, osudivati, blatiti, grditi, kritizirati koji u međusobnome odnosu jesu primjeri bliskoznačnosti.

Brzi uspon u hijerarhiji osvećuje se pad/om u onome što okupira ovaj mladi duh... (112)

Hergešić je rasipnik u stvarima iz kojih štedljivci grade akademijsku besmrtnost: u činjenicama. (114)

Iako u popisu ne nalazimo označene antonime kao imenice, navode se glagoli štedjeti - rasipati.

Navodimo nekoliko primjera suprotnoga odnosa iz feljtona:

...i kakva li je samo razlika u raspoloženju pri ulasku i izlasku iz konzerve nakon erotske agresije? (22)

Živeći od udisaja i izdisaja, tragajući za hranom i boreći se s neposrednim opasnostima... (29)

Izdvojene primjere ne nalazimo u rječniku $\mathrm{u}$ istoj formi, nego se navode tvorbeno drugačiji oblici - izdisanje - udisanje.

Od prve borbe za kisikom pa do skončanja ljudsko biće proizvodi nasilje gubeći se u krajnostima ljubavi i mržnje, siromaštva i bogatstva, istine i laži. (32)

Odnos između leksema ljubav - mržnja vektorne je naravi, antoniman odnos između siromaštvo - bogatstvo kvalitativan je te se još navode blagostanje, obilje, izobilje kao antonimni niz. Odnos između izraza istina - laž komplementaran je, a uz laž navode se i obmana, priča i zabluda s tim da je zadnji leksem u nepravome antonimnom odnosu s leksemom istina. 
d) Navedeni antonimi primjeri su kvalitativne suprotnosti, što znači da se odnose na kontrarne pojmove i čine krajnje članove slijeda. Primjeri su iz eseja:

Strastveni bal anđela i đavola koji periodično mijenjaju uloge, kako već koji dođe na red, bio je u biti ples prošlosti, katkad u dobro znanim koreografskim rješenjima, za koja smo držali da pripadaju povijesti. „Prateći vod“ uglavnom je šutio i hvalio ili kudio i jedne i druge. (172)

Za navedeni odnos između leksema navodi se oblik $u$ pridjevu đavolski - anđeoski, dok je odnos anđeo - vrag primjer kvalitativne antonimije.

Samo uz starog majstora moglo se smoći snage za tako plodan dijalog tradicije i modernosti. (162)

Napominje se samo da je u popisu naveden pridjevni oblik, a uz tradicionalan naveden je i leksem drevan kao kvalitativan antonim.

Goranov mjernik iz jame broji korake $u$ atriju smrti, vodi računa o metodologiji te smrti i određuje mjeru svjetlosti u svojemu vječnom mraku. (119)

Uz navedeni antonimni par mrak navodi se i tama kao leksem suprotan leksemu svjetlost.

Tamo gdje veseli činovnici pišu tugaljivu poeziju, tragični Tin kiptio je vedrinom, energijom i strašću. (142)

Kao prvi antonimni par uz leksem veseo navodi se tužan, neveseo, zatim leksemi koji su s njima u bliskoznačnome odnosu: mrk, snužden, sumoran, tmuran, kiseo, tugaljiv, žalostan, bezvoljan, čemeran, otužan.

Navodimo nekoliko primjera suprotnoga odnosa iz feljtona:

Čovjek samo gleda i sluša, opčinjen pukim gledanjem; on postaje sve manjim a televizija sve većom. On sve nemoćniji, ona sve moćnijom. (8)

Oba izdvojena primjera antonimnosti jesu u kvalitativnu odnosu. 
Oni jači uzimlju što im se hoće, slabiji iskušavaju umijeće mimikrije i pritajeno žvaču čemer neuspjeha. (30)

Ni mlad ni star, ni mršav ni debeo, bljedunjav, strogih crta lica, zagledan pozorno ispred sebe, da ne ugazi u kakvu lokvu, inače gotovo nevidljiv. (59)

Oba primjera nalazimo u rječniku u kvalitativnu odnosu.

e) Navedeni leksemi su u konverzivnome odnosu suprotnosti, što znači da je u takvu odnosu bitna zamjena mjesta elemenata iskaza - uzročnoga i posljedičnoga - dakle, isti se odnos promatra s različitih točaka. Slijedi primjer iz eseja:

Obojica su umrli od iste boljke, raka na grlu, učenik u kasnijim godinama od učitelja: cigarete, cigarete, cigarete. (143)

Za navedeni odnos antonimije nismo pronašli primjer u feljtonima, a s obzirom na to da je i u esejima pronađen jedan primjer, možemo zaključiti da takav tip antonimnosti nije čest.

\section{Antonimija uvjetovana kontekstom - antonimičnost}

Slijedi dio vezan uz antonimičnost, odnosno pojavu jezične suprotnosti uvjetovane kontekstom. Budući da je taj odnos dobrim dijelom opisan u djelu Ljiljane Šarić Antonimija u hrvatskome jeziku: semantič$k i$, tvorbeni i sintaktički opis, samo se ne navodi pojam antonimičnost, autoričina zapažanja o vrsti tih odnosa i njihovoj klasifikaciji poslužit će za razvrstavanje primjera iz analiziranih eseja i feljtona Veselka Tenžere.

a) Vrlo je često odnos suprotnosti u kontekstu uvjetovan vezom između antonima život - smrt, svjetlost - tama, staro - novo.

Slijedi nekoliko primjera antonimičnosti iz eseja:

I kao u antičkom mitu, u bečkom sužnju Eros i Thanatos opsjedaju biće. (164)

Uz osnovno značenje koje je u priručnicima navedeno kao prvo, Eros i Thanatos jesu grčka mitološka bića, bogovi - Eros za ljubav ili život, a 
Thanatos/Tanatos za smrt, destrukciju. Drugo značenje koje nalazimo uz leksem Eros jest (psih.) 'kreativna snaga koja proizlazi iz libida, uključuje skup impulsa čija je svrha održanje života, opr. Tanatos' (Anić).

Čovjek koji se tako lako gubi u sitnicama i tako olako ruga životu, u trenucima krize pretvara ga u himnu i u vatru koja cijepa tminu klonuća i sumnja. (119)

Opreka između leksema vatra i tmina u navedenome kontekstu proizlazi iz odnosa svjetlost - tama. Uz leksem vatra navodi se značenje sjaj, svjetlost (Anić) i određuje se kao proces sagorijevanja gorivih tvari pri čemu nastaje svjetlosna energija. Leksem tmina objašnjava se leksemima tama, mrak u svim konzultiranim priručnicima.

\footnotetext{
Starojugoslavenska tiranija, s potisnutim i duboko zapretanim makedonskim imenom, dala je jedan od onih tamnih okvira u kojima bljeskovi poezije nisu samo emocionalni nacrt opstanka, nego i provale energije srca jednoga naroda, kojoj se, u dosad poznatoj historiji, ništa nije moglo suprotstaviti. (146)
}

I u prethodnome primjeru imamo odnos suprotnosti utemeljen na razlici u značenju između antonima svjetlost - tama s tim da se navedeni leksemi razlikuju po vrsti riječi. U značenju svjetlost naveden je leksem bljesak za koji u svim priručnicima nalazimo značenje svjetlost, svjetlo, odsjaj, sjaj.

Slijedi nekoliko primjera antonimičnosti iz feljtona:

Pokazalo se, pak, da i umjetnost - koja je odvajkada igrala na kartu čovjeka $i$ života, a protiv dogme i tiranije svakoga neba - nerado napušta dojučerašnju povišenu poziciju... (40)

U izdvojenome primjeru radi se o višečlanome izrazu pa se suprotni odnos koji postoji između izraza temelji na suprotnosti između leksema život i nebo, odnosno život i smrt kada se u obzir uzme simbolika riječi nebo. 
...nastojao je da na tome kratkome i trnovitome putu između radanja i smrti sam sebi previše ne smeta i da ne pravi patnju iz stvari u kojima se može i uživati. (17)

Oba izdvojena primjera antonimičnosti temelje se na odnosu koji imaju leksemi život i smrt s tim da u posljednjem primjeru ta veza nije toliko očita jer je jedno predstavljeno kao dobro (dakle život - uživanje), a drugo kao loše (smrt - patnja). Da bi opreka bila vidljiva, potrebno je u obzir uzeti i negirani oblik glagola uz patnju.

Ostat će i dalje tihi, skriveni mjesečari, pozvani u svijet bez mjesta za njih, jer su drugi tako široki da, ako im i za smrt bude potrebno toliko prostora kao za život, netko će, zna se tko, biti podstanar i na onome svijetu. (49)

Među izdvojenim primjerima imamo očitu antonimiju život - smrt, dok su drugi primjeri (svijet bez mjesta za njih - na onome svijetu) uvjetovani kontekstom, ali im suprotnost počiva na vezi između leksema život i smrt, odnosno ovozemaljsko - onozemaljsko.

b) Kontekstualna se suprotnost može postići i negiranjem značenja jednoga od leksema koji sudjeluje $\mathrm{u}$ antonimičnome odnosu.

Navodimo nekoliko primjera takve vrste antonimičnosti iz eseja:

Briljantan u kratkoj formi, u skici, u evokaciji svojih tjeskoba, ali i zagušen učenim asocijacijama, humanističkom manirom, mitološkim scenarijem koji je više gimnastika duha u tami negoli potraga za vlastitim poetskim identitetom. Tu negdje odlučuje se i sudbina njegova pjesništva: iskrenost nije nadvladala učenost, pjesnik je rijetko pobjeđivao humanista vješta zanatu stihovanja. (112)

Prvi označeni primjer (gimnastika duha u tami - potraga za vlastitim poetskim identitetom) predstavlja izričito kontekstualno uvjetovanu suprotnost, a u ovome slučaju to je zbog veznika negoli. Analizom značenja svakoga od navedenih leksema višečlanih suprotnih izraza ne može se staviti u opreku nijedan od leksema izvan ovoga konteksta. Značenja leksema iskrenost i učenost također nisu međusobno suprotstavljena izvan konteksta, opreka nastaje zbog negiranoga glagola. Isto 
vrijedi i za lekseme pjesnik i humanist, a opreka je nastala zbog negiranja glagola prilogom rijetko.

Sve strasti su obuzdane i svaka pripadnost treba biti provjerena na oštrici svagda budne misli: ekspresionizam je tada naprosto polazna postaja za velike pisce i završna za one koji to nisu. (121)

$\mathrm{U}$ navedenome primjeru leksemi polazan - završan stoje u antonimičnome odnosu jer im suprotnost zapravo proizlazi iz odnosa antonima početak - kraj. Drugi je primjer u antonimičnome odnosu isključivo zbog konteksta. To je višečlani izraz čije sastojnice nisu iste po vrsti riječi, a suprotnost je ostvarena odnosnom atributnom rečenicom (one koji to nisu) kojom se negira sintagma veliki pisci.

$\mathrm{Za}$ isti odnos navodimo nekoliko primjera iz feljtona:

Onih nekoliko pajzlova, s ambicioznim svjetlećim nazivom „BAR“, bili su više slivnici za poraze dana negoli pozornice za užitke noći. (18)

Nositelji suprotnosti u izdvojenim primjerima jesu leksemi dan noć, ali kontekstualna suprotnost višečlanoga izraza pojačana je suprotnim veznikom negoli.

Dakle Matoš nije dobio spomenik nego posao koji za života nije mogao osigurati. (69)

U ovome primjeru suprotnost je postignuta zahvaljujući vezniku nego.

Jesmo li ih možda približavali Bogu ili smo ih udaljavali od nas... (71)

Nositelji suprotnosti ovih izraza jesu leksemi približiti - udaljiti, ali i neizravna veza koja postoji između leksema Bog - mi utemeljena na odnosu sveto - profano, božje - ljudsko. Suprotnost ovih izraza dodatno je naglašena i rastavnim veznikom ili što tekst u cjelini ovakvi i slični primjeri čine ekspresivnijim. 
Tek nešto veselije djeluju natječaji ili puka naklapanja o revitalizaciji Gornjeg grada. (73)

Je li to iz dubine krvi prastari nomad osluškuje stepu ili to gradski ilegalac očekuje grubo kucanje na vratima? (48)

U oba prethodna primjera suprotnost je postignuta zahvaljujući kontekstu, odnosno isključivanjem jednoga od izraza uporabom veznika ili.

Čim se počelo prodavati nešto više cipela nego opanaka, paničar je zaurlao o histeriji potrošnje... (54)

Opreka između navedenih izraza uzrokovana je negacijom jednoga od navedenih, s tim da se može govoriti i o opreci koja postoji između leksema staro - moderno.

Rezervat iz kojega je izišao to mu nije praštao, svijet $\mathrm{u}$ kojem je uspio nije trebao osobe nego fabrikate. (42)

Odnos suprotnosti između leksema rezervat i svijet, s obzirom na kontekst, temelji se na opreci između leksema početak i kraj, dok je drugi primjer (osoba - fabrikat) suprotnosti rezultat negacije jednoga od izraza.

c) Osobita se stilska izražajnost postiže uporabom stilskih figura utemeljenih na suprotnosti (oksimoron, antiteza).

Slijedi nekoliko primjera iz Tenžerinih eseja:

Ne vjerujem da to samo moj dojam, ali čini mi se da je Ujević već danas svojevrsna off-vrijednost hrvatske književnosti, koju gradimo i dalje na Barčevoj „veličini malenih“: ugurati Ujevića u takvu koncepciju nacionalne književnosti nalikovalo bi guranju slona u dječja kolica. (144)

Izdvojena sintagma primjer je oksimorona i tvori jedinstven pojam, a njezine sastavnice međusobno su suprotnoga značenja.

Diveći se, mi želimo razlog divljenja pomiješati sa svim stvarima koje cijenimo, gubeći ga kao cjelinu da bismo ga sačuvali u fragmentima. (135) 
U izdvojenim primjerima nositelji suprotnosti odnosno antonimičnosti jesu leksemi cjelina i fragment zbog kojih cijeli izrazi dobivaju suprotno značenje. Iako je općepoznati antonim glagolu gubiti glagol naći/ nalaziti, zbog konteksta u kojem su se izrazi našli to je glagol sačuvati.

Iznimne ličnosti u malim narodima obično zaglave u legendama. Skriveni u nišama ili propeti na postamente traju iznad linije svakodnevnog motrenja. Skeptičan duh poslije i ne zna jesu li podignuti tako visoko da budu primjer ili opomena: eto, to su ostaci sna koji je smjerao preko postojećeg. Aura svetosti lako postaje omčom vješala: treba samo izmaknuti postament. (163)

U prvome primjeru leksemu izniman u navedenome kontekstu dano je značenje 'velik', iako u priručnicima to značenje ne nalazimo, samo značenja 'osobit, poseban, rijedak, izvanredan' kojima ovaj leksem djelomično, a pri tome mislimo u prenesenome značenju, može stupiti u odnos suprotnosti s leksemom malen. Sljedeći primjer u obliku sintagme antonimičan odnos temelji na leksemima niša (sa značenjem 'udubljenje u zidu za smještaj kipova, vaza ili predmeta') i postament (sa značenjem 'postolje za veliku stvar'), a time su suprotstavljeni i glagoli skriveni i propeti. Leksemi primjer i opomena međusobno su suprotstavljeni zahvaljujući vezniku ili kojim je izrečena opreka. San sa značenjem 'duševna aktivnost za vrijeme spavanja u obliku manje ili više iracionalnih slika i predodžaba; snivanje' (Šonje) stupa u odnos suprotnosti s leksemom postojeći u značenju 'koji postoji, koji jest; egzistirajući, stvarni'. Za izraze aura svetosti i omča vješala ne nalazimo opravdanja u priručnicima za suprotan odnos izvan navedenoga konteksta.

Slijedi nekoliko primjera antonimičnosti iz feljtona:

Uostalom, Lari Kent je jeftiniji od Shakespearea, a laka glazba od klasične. (17)

U navedenome primjeru odnos suprotnosti počiva na odnosu koji postoji između leksema staro - novo/moderno, s tim da su vlastita imena uporabljena u metonimijskoj funkciji. Suprotnost je dodatno pojačana suprotnim veznikom $a$ i usporedbom. 
Sve dogme ružne su u usporedbi sa ženskim linijama ili muškim volumenima... (17)

Nositelj suprotnosti u ovome primjeru jesu leksemi ženski - muški poradi čega su u ovome kontekstu i leksemi linija - volumen suprotni, a dodatno je pojačana i rastavnim veznikom kojim se jedan od izraza isključuje iz teksta.

Ružno bogatstvo sjevera i lijepo siromaštvo juga činili su tako stoljećima simetriju u kojoj nije bilo pravde, ali je bilo neke razumljive ravnoteže. (35)

Kada se pojedini članovi izdvojenih primjera promatraju zasebno, čine prave antonime, međutim stilska osobitost ovih primjera jest njihova višečlanost čime se suprotnost pojačava kao i kontekstom u kojem su se našli.

Paradoks je bio kompletan: relativno brz rast materijalnoga, i nešto sporiji kulturnoga standarda kvalificirao je doslovce milijune ljudi za tzv. kulturni život...(41)

Nositelji suprotnosti u ovome primjeru jesu izrazi brz - spor čime je i preostali dio izraza suprotstavljen u navedenome kontekstu.

d) Stavljanjem leksema ili sintagmi u netipične sveze koje su u suprotnome odnosu unutar nekoga (kon)teksta, pojačava se ekspresivna vrijednost teksta.

Iz eseja smo izdvojili sljedeće primjere:

S druge strane, na kalendaru naših proslava mač ima prednost nad olovkom, tako da i one rijetke datume nacionalnoga genija obilježavaju uglavnom samo stručnjaci. (107)

Značenja se leksema mač i olovka ne mogu dovesti u suprotan odnos izvan navedenoga konteksta. U ovome kontekstu značenje je navedenih leksema metonimijsko jer je u daljnjem tekstu vidljiva zamjena značenja pa mač zamjenjuje stručnjake, a olovka genije. 
On svojim mediteranskim redikulima ulazi na scenu života i u toj vječnoj igri opsjene i zbilje pronalazi drhtavu stanicu života... Redikul tako postaje jednadžbom korodirane društvenosti, biće kojega je donkihotski lijepa misao osudila na unutarnju emigraciju, simbol jednoga kolektiviteta što ne otvara u sebi dovoljno prostora za individualno. (130)

U priručnicima se uz leksem opsjena navode leksemi obmana, varka, pričin kao sinonimni, a uz leksem zbilja sinonimni izrazi su stvarnost, realnost. Kod Šonje je kao druga definicija s oznakom fil. navedeno i sljedeće značenje 'ono što uistinu postoji nasuprot pojavi koja se pojavi i nestane, ili priviđa, koja se samo čini da postoji'. Dakle, dani kontekst aktivirao je dijelom specificirano značenje navedenih leksema da bi se između njih uspostavio suprotan odnos. Drugi primjer funkcionira kao antonim, dakle i bez navedenoga konteksta, a izdvojen je poradi toga što se radi o različitim vrstama riječi koje se izvan konteksta ne bi stavljale u opoziciju.

Nakon Šimićeva slobodnog stiha u Hrvatskoj više nemamo značajnije vezane poezije (Ujević se javio ranije), što je upravo fantastičan koliko i poguban utjecaj. Poslije njegove filozofije očitosti i ekonomije jezika gotovo da i nemamo blagoglagoljivih pjesmurina i provincijske ljubavi za „pravilne“ gredice metrike. (120)

U navedenome ulomku imamo više različitih odnosa s obzirom na suprotnost, ali i broj članova izdvojenih izraza. Odnos između sintagmi slobodan stih i vezana poezija antonimičnost temelji na vezi slobodan - vezan kada se govori o vrsti stiha odnosno rime, a zbog toga su i leksemi stih i poezija stavljeni u antonimičan odnos zahvaljujući kontekstu. Antonimičnost između leksema fantastičan i poguban postoji samo unutar navedenoga konteksta s tim da je u ovome kontekstu aktivirano značenje leksema fantastičan - 'izvanredan, golem' - koje je u priručnicima označeno kao razgovorno. Posljednja četiri izdvojena primjera $u$ obliku sintagmi suprotan odnos ostvaruju isključivo unutar navedenoga konteksta, a suprotnost dodatno naglašava negirani glagol. Antonimičan odnos čine filozofija očitosti u odnosu na blagoglagoljive pjesmurine te ekonomija jezika u odnosu prema provincijska ljubav, a pri tome 
nijedan od navedenih leksema nijednim svojim značenjem ne može biti u opreci izvan navedenoga konteksta. Zapažamo i ironičan autorov stav prema navedenim pojavama u društvu odnosno književnosti, osobito u izrazima filozofija očitosti i blagoglagoljive pjesmurine, a u posljednjem i porugu zbog uporabe uvećanice.

Umro je, dakle, pisac koji je za života upoznao ogorčenje i slavu, prešućivanja i priznanja, osude i nagrade. (157)

Izdvojeni su primjeri antonimični u ovome kontekstu, ali izvan konteksta se ne bi mogli staviti u opreku osim primjera ogorčenje i slava, ali djelomično. U navedenoj rečenici imamo i kontekstualno uvjetovane sinonime i to ogorčenje - prešućivanje - osuda s jedne strane i slava priznanja - nagrade s druge strane.

$\mathrm{Za}$ istu vrstu antonimičnosti navodimo primjere iz feljtona:

A svi iz iskustva znamo kolika su djeca sjajnih brakova postala notorne hulje, dok su ona iz socijalnog pakla postajala sjajni ljudi. (74)

Odnos među izdvojenim primjerima temelji se na vezi između suprotnih leksema dobar - loš (sjajni brakovi - socijalni pakao) i nepoželjan - poželjan (notorne hulje - sjajni ljudi).

Velika matematika i bijedna nogometna stvarnost lome srca i nade, vraćajući buduće milijunaše na obične plaće i uskraćujući dugonogim gerlama neslućene zabave. (54)

Nositelj suprotnosti u prvome izdvojenom primjeru jesu leksemi velika - bijedna s napomenom da u ovome kontekstu njihov odnos počiva na vezi koju imaju leksemi slavan - neslavan, dok drugi izdvojeni primjer svoju opreku temelji na odnosu koji postoji između antonima siromašan - bogat.

Savršeno pomirenje prirode i kulture: krokodil-žderonja pretvorio se $\mathrm{u}$ torbicu za kozmetički pribor, goropadni medo glumio je sag, krvoločna pantera grijala je krhka leđa namijenjena suptilnijim pandžama, lukava lisica savila se u kragnu. (57) 
Antoniman odnos koji se javlja među navedenim primjerima počiva na suprotnu odnosu koji postoji između prirode i kulture, a također je uvjetovan kontekstom i to negativnim jer su prirodne blagodati uništene zbog kulturnih prohtjeva ili hirova, što pokazuju nabrojani primjeri.

...ta ljepotica možda uviđa da se uništenom sadašnjošću ne može kupiti bolja budućnost, ali je kasno. (34)

Nositelji suprotnosti u navedenome primjeru jesu leksemi sadašnjost - budućnost, a leksemi uništen i bolji u ovome kontekstu aktivirali su posebno suprotno značenje koje počiva na odnosu između leksema pozitivan - negativan.

e) Kod nekih leksema svojstvo suprotnosti uočava se tek stavljanjem riječi u odgovarajući kontekst, a time se zapravo otkrivaju unutarnje suprotnosti.

Primjeri iz eseja čija je suprotnost utemeljena na dubinskim strukturama riječi:

Prešutni sporazum negdje u podnožju povijesti, da je idealima mjesto na papiru a ne u životu, jedan je od izvora tragedije. Uvijek se tako nađe neki vitez tužnoga lika da izazove kratki spoj idealnoga i zbiljskoga i da ponese žig prognanika. (130)

Prvi primjer opreku temelji na suprotnome vezniku $a$, inače se za ta dva leksema u priručnicima ne navode značenja koja bi se aktivirala u navedenome kontekstu i tvorila opreku. Budući da se u priručnicima pri određenju sljedećih leksema zapravo upućuje na imenicu (ideal i zbilja), poslužit ćemo se definicijama koje donose za njih. Zbilja se određuje kao stvarnost, realnost, istina, java, a kao opreka za posljednja dva značenja navode se san, mašta, priviđenje, prividnost. Ideja se, između ostaloga, definira na sljedeći način: 'početna misao; naum, nakana, plan, nacrt, zamisao', psih. 'predodžba ili misao koja se u svijesti pojedinca javlja i obnavlja remeteći normalnost psihičkog života'. Primjećujemo da se objema definicijama poistovjećuje s leksemima misao, zamisao 
koji su apstraktni pa je na odnosu apstraktan - konkretan zasnovan i oprečan odnos između zbilje i ideala, odnosno zbiljskoga i idealnoga.

Što mi znamo o tim pjesmama i što nam one znače? Kad sve saberemo i odbijemo sve nebitno, ostaje nekoliko ocjena tipa - izvrsno, fantastično, zgodno i slične poslastice kritičarskih neuspjeha. (133)

U ovome kontekstu značenje leksema sabrati jednako je onomu leksema zbrojiti/zbrajati - 'izračunavati ukupan broj ili iznos čega' - pa bi za očekivati bilo da su mu oprečni leksemi oduzeti/oduzimati. Međutim, i uz leksem odbiti nalazimo značenje 'oduzeti od iznosa, ne uračunati' koje je aktivirano u navedenome kontekstu, a na osnovi čega ta dva leksema tvore opreku.

Stjecajem povijesnih i kulturnih okolnosti, naime, mi smo prečesto sužavali fenomen književnog djela u dnevne koordinate, gdje smo ga onda nezasluženo veličali ili zanemarivali. (154)

O djelomičnoj antonimiji između izdvojenih leksema možemo govoriti i izvan navedenoga konteksta ako uzmemo u obzir da se zanemarivati određuje sinonimom zapuštati, a veličati sinonimima uzdizati, uzvisivati. No, u navednome kontekstu ta djelomičnost prelazi u pravu suprotnost poradi rastavnoga veznika ili.

Iz feljtona navodimo sljedeće primjere ove vrste opreke:

Ekonomska kriza ili politički konflikt, predočeni na ekranu, nemaju nikakva izgleda da budu zapamćeni kao smoking nekog drekavca ili bijesna haljina kakve pjevaljke. (9)

Među izdvojenim primjerima ne nalazimo izravnu vezu koja bi se temeljila na suprotnosti, nego je ona uvjetovana kontekstom i dodatno pojačana uporabom rastavnoga veznika ili. Jedino bi se u posljednjem antonimičnom paru mogla naći veza suprotnosti vezana za odnos između leksema muško - žensko na što upućuju izrazi smoking i haljina te drekavac i pjevaljka. 
Žena udružena s televizijom, ili televizija udružena s punicom, učinili su od muškarca tipa kojemu stolac za gledanje televizije pretvaraju u optuženičku klupu. (9-10)

Antonimična veza navedenoga primjera vezana je isključivo za kontekst i uporabu rastavnoga veznika ili, a izdvojeni primjeri su i svojevrsna igra riječima čime autor postiže komičan učinak.

Na kraju svakog turističkog ljeta nadaje se pitanje: što je Jadran za nas? Prostitutka čije draži krčimo bez milosti ili dar prirode koji uvećava naše životne mogućnosti? (34)

Suprotnost između izdvojenih primjera počiva na kontekstu pri čemu autor rabi pojmove koji sa sobom nose negativne (prostitutka) i pozitivne (dar prirode) konotacije bez obzira na kontekst čime se dodatno želi naglasiti problem o kojem piše.

U sudaru između elite i masovne koncepcije turizma rodio se današnji jadranski bastard: elitisti su upravo toliko nametnuli svoje programe da iz turističkog partera izbace domaćega gosta, a masovnjaci su cijene zauzdali na razini koja još odgovara najnižoj kategoriji zapadnih turista. (36)

Suprotnost izdvojenih izraza uglavnom je vezana za značenje koje su riječi elita i masovnjaci dobili u navedenome kontekstu - vrh - dno, pa su u skladu s tim okarakterizirana i njihova djela kao suprotna, uz napomenu da oba izraza u tome kontekstu imaju negativne konotacije za autora, a izraz masovnjaci i pejorativnu oznaku.

Spadam u red onih koje podilaze žmarci od ljudi koji se služe unosnim, nosećim, aktualnim klišejima tipa: zagrebački malograđani sprečavaju me da podignem moderna čudesa pokraj agramerskih ćumeza. (91)

Među izdvojenim leksemima ne nalazimo suprotan odnos bez navedenoga konteksta. 
...pošto je svoje simpozijaške kolege cijelog sata plašio gubitkom kisika, kojega ima navodno tako malo, da bi većina morala šaptati e da bi se manjina mogla, bez opasnosti od gušenja, smijati. (23)

Suprotan, antonimičan odnos između izraza većina - manjina postoji izvan navedenoga konteksta, ali su ti izrazi bitni za odnos suprotnosti između šaptati - smijati, pa smo ih stoga izdvojili, dakle oni su taj potreban kontekst unutar kojega se ostvaruje antonimičnost.

f) Suprotan odnos može biti utemeljen i na preuveličavanju - hiperboli.

U ovome dijelu rada izdvojeni primjeri uglavnom su višečlani izrazi u kojima se obično izdvaja po jedan leksem kao nositelj suprotnosti cijeloga izraza. Takav postupak, da se na temelju jednoga leksema imenuju cijeli izrazi, ili u našem slučaju temelji odnos suprotnosti, preuzet je od M. Samardžije koji on koristi za određenje vrste frazema s obzirom na prevladavajuću vrstu riječi (imenski, glagolski, pridjevni, priložni). ${ }^{37}$

Navodimo nekoliko primjera iz eseja:

Od siromašna studenta do šefa hebraističke katedre u Lutherovu Wittenbergu, od učenjaka širokih odjeka do polemičara na trnovitu putu progonstva, ispisivana je jedna intelektualna biografija s fascinantnim tragom na duhovnoj mapi Europe. (107)

Prvi par siromašan student i šef hebraističke katedre svoju opreku temelji zapravo na odnosu siromašan - bogat jer se za nekoga tko je šef pretpostavlja da je bogat. Ako u obzir uzmemo i leksem student, onda se opreka može temeljiti i na odnosu zaposlen - nezaposlen. Drugi par svoju opreku temelji na odnosu poznat - nepoznat odnosno priznat ( $\mathrm{u}$ društvu) - nepriznat. Iz posljednjega je vidljiv i autorov odnos prema nekim društvenim pojavama ili zanimanjima - teško je biti polemičar $u$ društvu u kojem pravila određuju „stručnjaci“.

37 Usp. M. SAmARDŽIJa, $n$. dj., str. 87. 
Nakon Ferrare slijedi studij prava u Padovi i, naravno, povratak u Panoniju gdje jezik oružja i zatucanosti odmjenjuje mladiću učene humanističke dispute s biranim duhovima toga vremena. (111)

Antonimičnost u ovome primjeru počiva na odnosu između leksema zatucanost - učen i oružje - humanistički. Leksem zatucanost, odnosno pridjev kojim se definira u priručnicima - zatucan, stoji u sinonimnome odnosu s leksemima zadrt, zaostao, zalupan između kojih postoji djelomična antonimija u odnosu na učen. U ovome kontekstu leksem oružje simbolizira borbenost, sirovost u postupcima ljudi, a u odnosu na to imamo humanističke dakle ljudske, čovječne, suosjećajne rasprave. Antonimičnost je dodatno pojačana i leksemom odmjenjivati - 'preuzeti čiji teret, posao, dužnost na neko vrijeme; zamijeniti'.

I danas strpljivije od mnogih traži stvaralačke zaloge predstave, dok većina drugih tek prakticira cinizam kazališnih kuloara. (116)

Analizom izdvojenih izraza ne može se pronaći veza među leksemima koji bi bili suprotni i izvan navedenoga konteksta. Suprotnost između ovih sintagmi počiva isključivo na navedenome kontekstu prema kojem na jednoj strani imamo zalaganje, trud, stvaralačku djelatnost ozbiljnih poznavalaca kazališta, a na drugoj ironičnu drskost sporednih osoba koji su samoprozvani stručnjaci kazališnih djelatnosti.

Nakon oranice čekao ga je stroj, nakon sijela s popijevkama čekale su ga monotone noći u novogradnjama, nakon deset Božjih zapovijedi upao je u svojevrsnu revoluciju morala i običaja. (...) Prostrana livada na kojoj je živio u kakvom-takvom skladu s ritmom godišnjih doba zamijenjena je tjeskobnim stanom u kojemu je monotonija već postala mjerom budućnosti. (175)

Navedeni su primjeri uvjetovani isključivo kontekstom. Prva tri para primjera svoju opreku temelje na simboličnome značenju pa je tako odnos između leksema oranice - stroj jednak odnosu fizički rad - umni rad, odnos između sintagmi sijela s popijevkama - monotone noći u novogradnjama jednak odnosu zanimljivo - dosadno i treći primjer deset 
Božjih zapovijedi - revolucija morala i običaja jednak je odnosu sveto - profano. Četvrti, posljednji primjer antonimičnost oblikuje na drugačiji način jer po jedan od leksema oba izraza nositelj je antonimičnosti cijeloga izraza, a to su prostran i tjeskoban.

Navodimo nekoliko primjera iz feljtona isključivo kontekstualno uvjetovane suprotnosti:

U tijekovima zanemarene, ali vrlo važne revolucije osjećajnosti, stiješnjene između brutalizma avangarde i imbecilizma masovne zabave, između elitnoga hermetizma i agresivnoga kiča, Arsen Dedić je stvorio poetsku leguru rijetke dojmljivosti, s pečatom osobnoga i s masovnim odjecima. (45)

U prva dva primjera suprotnost je vezana isključivo za kontekst, mada bi se u drugome primjeru moglo reći da postoji i veza suprotnosti između izraza elita i kič kao nešto nedostižno i dostižno. U trećem primjeru na temelju leksema osobno i masovno pronalazimo suprotnu vezu u njihovim značenjima kao privatno i javno koji su onda nositelji suprotnosti cijelih izraza.

...ali ova je bila sasvim pristojna, kao iz neke anonimne srednjoeuropske kraljevine, gdje solidan obrt zamjenjuje krupne strasti. Kovački mijeh $i$ rad, na primjer, umjesto mača i pustolovine. (56)

Prvi navedeni primjer svoju opreku temelji na značenju koje proizlazi iz navedenoga konteksta u kojem solidan obrt označava nešto konkretno, a krupne strasti apstraktno. Iz toga odnosa proizlazi i suprotnost drugoga primjera jer kovački mijeh $i$ rad podrazumijevaju fizički rad, mač i pustolovina duhovni rad odnosno nerad.

...sociološkog šunda u kojemu pratimo sve varijante borbe između zle Eve i zatucanog roba Adama u jednoj verziji, a u drugoj naričemo nad sudbinom obespravljene žene podvrgnute talokratskoj tiraniji iskompleksiranog Adama. Čak i u našim uvjetima, u kojima se patrijarhat još dobro drži, a feminizam pothranjuje tek lijenošću stanovitog tipa žene...

(62) 
U navedenome slučaju opreka svih izdvojenih primjera utemeljena je na opreci muško - žensko pri čemu se autor u prva dva primjera poslužio biblijskom terminologijom. Usto ta prva dva primjera višečlani su izrazi u kojima je broj članova različit $\mathrm{u}$ istome paru, pa se suprotna veza među pojedinačnim leksemima i ne može tražiti zbog nejednakoga broja jezičnih jedinica. Posljednji primjer je jednočlani izraz, ali je opreka isključivo kontekstualna jer bi pravi antonim patrijahatu bio matrijarhat.

Žene su tako postale rječnici muškog svijeta u šlapoidnoj varijanti: što nakićenija gospodarica, to vredniji rob, što bogatiji izgled kućne vladari$c e$, to i veći uspjeh njezina sluge u životu. (65)

Suprotnost u ovome primjeru već je navedena u samome tekstu, dakle radi se o suprotnosti između muškarca i žene, samo što se odnos temelji na suprotnosti koju nalazimo među leksemima nadređen - podređen pri čemu je muškarac ovo drugo, što je vidljivo i iz uporabe zamjenskih leksema za muškarca - rob i sluga s negativnim konotacijama.

\section{Zaključak}

Izdvojeni primjeri analiziranih feljtona i eseja pokazuju kako dubinska struktura riječi dolazi do izražaja unutar (kon)teksta. Premda su u prvome dijelu navedeni primjeri prave suprotnosti, antonimije, zahvaljujući kontekstu u koji su smješteni, doprinose većoj ekspresivnosti jezika i stilskoj dotjeranosti izraza. Ekspresivnost i stiliziranost izraza osobito je vidljiva u drugome dijelu u kojem su izdvojeni izrazi i sintagme međusobno suprotni isključivo zbog konteksta - antonimičnosti. Primjeri takve suprotnosti, postignute primjerice uporabom stilskih figura ili stavljanjem različitih riječi u neobične sveze, utječu na stilsku izražajnost.

Nadalje, osobito učinkoviti u oblikovanju jasna, dosjetljiva, duhovita, individualnom notom obojana jezika jesu višečlani antonimični izrazi čija se površinska struktura u potpunosti gubi iz vida zbog konteksta, a povećava se ekspresivnost teksta. 


\section{Literatura}

- Anić, Šime - Klaić, Nikola - Domović, Želimir, Rječnik stranih riječi, Sani-plus, Zagreb, 2002.

- Anić, Vladimir i dr. (ur.) Hrvatski enciklopedijski rječnik, Novi Liber, Zagreb, 2003.

- Anić, Vladimir, Veliki rječnik hrvatskoga jezika, Novi Liber, Zagreb, 2006.

- Babić, Stjepan, Jezik, Panorama, Zagreb, 1967.

- Black, Elisabeth, Pragmatic Stylistics, Alan Davies - Keith Mitchell (ur.), Edinburgh University Press, Edinburgh, 2006.

- Enciklopedija.hr, www.enciklopedija.hr.

- Frančić, AnĐela - Mihaljević, Milica, „Antonimija u hrvatskoj ojkonimiji“, Rasprave IHJJ, god. XXIII. - XXIV. (1997. - 1998.) br. 1., str. 77. - 102.

- Katnić-Bakaršić, Marina, Stilistika, Ljiljan, Sarajevo, 2001.

- LEŠIĆ, ZdENKo, Jezik i književno djelo, Zavod za izdavanje udžbenika, Sarajevo, 1971.

- Melvinger, Jasna, Leksikologija, Pedagoški fakultet, Osijek, 1989.

- Mihaljević, Milica - Šarić, Ljiljana, „Terminološka antonimija“, Rasprave ZHJ, Zagreb, god. XX. (1994.) br. 1., str. 213. - 243.

- Petrović, Bernardina, Sinonimija i sinonimičnost u hrvatskome jeziku, Hrvatska sveučilišna naklada, Zagreb, 2005.

- Pranjić, Krunoslav, Jezik i književno djelo. Ogledi za lingvostilističku analizu književnih tekstova, Školska knjiga, Zagreb, 1968.

- Rječnik hrvatskoga jezika, Šonje, Jure (ur.), LZ „Miroslav Krleža“ - ŠK, Zagreb, 2000.

- Römer, Christine - Matzke, Brigitte, Lexikologie des Deutschen. Eine Einführung, Gunter Nar Verlag, Tübingen, 2005. 
- SamardžIjA, Marko, Leksikologija hrvatskoga jezika i povijest hrvatskoga jezika u XX. stoljeću, Školska knjiga, Zagreb, 1995.

- Stančić, Ljiljana, Sustavnost leksika i sinonimne relacije u klasičnom strukturalizmu, Institut za jezik, Sarajevo, 1991.

- ŠArIĆ, LJILjANA, „Antonimija: neke značenjske i tvorbene odrednice“, Rasprave ZHJ, Zagreb, god. XVIII. (1992.) br. 1., str. 177. 191.

- ŠArić, Ljiljana, Antonimija u hrvatskome jeziku: semantički, tvorbeni i sintaktički opis, Hrvatska sveučilišna naklada, Zagreb, 2007.

- ŠARIĆ, LJILJANA, „Kognitivna lingvistika i sinonimija: teorija i leksikografska praksa“, Croatica et Slavica Iadertina, Zadar, god. VII. (II.) (2011.) br. 7., str. 305. - 325 .

- Tafra, Branka, Od riječi do rječnika, Školska knjiga, Zagreb, 2005.

- Tenžera, Veselko, En Passant, Znanje, Zagreb, 1978.

- Tenžera, Veselko, Sadašnjost za vječnost - izbor iz djela, ZdRAVko Zima (prir.), Naklada Ljevak, Zagreb, 2005.

- Turk, Marija, „Neka odstupanja u antonimskoj simetriji u hrvatskom jeziku“, Fluminensia, Rijeka, god. XVI. (2004.) br. 1. - 2., str. 87. -94 . 


\section{LEXICAL AND SEMANTIC RELATIONS OF OPPOSITES CONDITIONAL UPON CONTEXT}

\section{Abstract}

The paper analyzes relations of semantic opposites among words in the feuilletons (En Passant) and essays (Sadašnjost za vječnost - selection from the works) by Veselko Tenžera, especially those conditional upon context. Since those relations are not visible outside the mentioned context, we call that phenomenon antonymy.

Examples of the real opposite or antonymy are given at the beginning of the paper, but due to the context in which they are put, they also contribute to greater language expressiveness and stylistic refinement of the expression. Expressiveness and stylization of the expression are especially evident in the second part of the paper which singles out expressions and syntagms mutually opposite solely because of the context antonymicity. Examples of such opposite, achieved by figures of speech or putting different words into unusual connections, influence on the stylistic expressiveness. That is especially the case with multi-part antonymic expressions whose surface structure is completely lost out of sight due to context, while the expressiveness of the text is increased.

Keywords: lexical and semantic relation; antonymy; antonymicity; context; Veselko Tenzera; essay; feuilleton; expressiveness; stylization 